\title{
Government Tax Policy and Performance of Listed Manufacturing Firms in Nigeria: Evidence from Dynamic Panel Data Model
}

\author{
Hammed A. Adefeso *
}

\begin{abstract}
This study examined the influence of government corporate tax policy on the performance of 54 randomly selected listed companies that cut across 17 categories of non-financial in Nigeria over a period of 1990-2002. Using Generalised Method of Moment (GMM) and contrary to the expectation, the study found positive relationship between corporate tax policy and the output performance of quoted manufacturing firms in Nigeria. This may be an indication that government revenue from corporate tax was judiciously expended on productive government expenditure most especially in Lagos State as virtually all the selected manufacturing firms have their main base in Lagos State. The study therefore recommended that Federal Government should either minimize or totally remove tax incentives, tax waivers and tax holidays to some manufacturing firms in Nigeria.
\end{abstract}

Keywords: government; corporate tax; tax policy; manufacturing firms; generalized method of moment

JEL Classification: $\mathrm{H}, \mathrm{H} 2, \mathrm{H} 25$

\section{Introduction}

In any economy, government participation in economic activities is largely determined and influenced by the type of economic system operating in that country. In a mixed economic system, which is predominantly practiced by most developing countries including Nigeria, that public sectors participated in the control of economic activities by means of public policy reforms along with the private sector is not a new dimension in the management of the economy. Government as an economic institution plays a vital role in the determination of the output performance

\footnotetext{
${ }^{*}$ Hammed A. Adefeso is at Faculty of Administration, Obafemi Awolowo University, Ile-Ife, Osun Nigeria.
} 
and capacity utilization of manufacturing industry in Nigeria. Apart from being the coordinating agent for manufacturing sectors and others, it also plays crucial roles in stimulating and influencing the market forces of demand and supply through its policy instruments.

The two major government policy instruments are monetary and fiscal policy through which it influences the developmental roles of the manufacturing sector. Though, the performance effect of monetary policy is less controversial, but the relevance of fiscal policy component of government policy to manufacturing firms' performance still remained the subject of empirical debate with inconclusive result in the literature. The most controversial component of fiscal policy is the tax policy possibly because of its role on the performance of manufacturing firms. Tax policy remains a major fiscal policy instrument of the government for generating revenue to meet up with public infrastructural challenges affect the production function of the manufacturing sector of the economy. Studies in developed countries suggest that by reducing marginal tax rates, or by replacing the federal income tax with a consumption tax, the work effort, saving, and investment can be increased, resulting in a tremendous increase in firms output performance.

The activities of manufacturing firms have significant impact on the development process of any economy as they account for a substantial proportion of total economic activities which reflect visibly in job creation and improved tax contribution in the developed economies. In recent times however, there has been a growing concern on the declining performance of manufacturing firms in Nigeria which have been characterized by declining productivity rate despite various strategies and reforms put in place by government. This slow performance has resulted in unemployment generation, which is caused largely by inadequate electricity supply, smuggling of foreign products into the country, high exchange rate, inadequate financial support and lack of proper harmonization and coordination of tax policy and this has led to multiplicity of taxes, specifically, as at 2002, 40 different taxes and levies are shared by all three levels of government according to (Adeoye, (2006) and number increased to 47 in 2013 as reported by World Bank. This undesirable performance of manufacturing firms in Nigeria has equally resulted into the reduction in capacity utilization and output of the manufacturing sector of the economy (Tomola, Adebisi and Olawale, 2012).

Literatures however, showed that there have been much studies in public finance (Lee and Gordon (2004), Koch, Schoeman and Tonder (2003)) in relation to its impact on growth, capital formation, capital stock, deficit and macroeconomic variables. However, adequate research on the nexus between tax policy and the manufacturing firms' performance has not been conducted in Nigeria as noted in the recent study of (Ezejiofor, 2015). Generally, while government is complaining of shortfall of tax revenue from manufacturing sector, the unimpressive performance in the sector has been attributed to problem of multiplicity of taxes (Micah, Ebere and Umobong, 
2012). This calls for an empirical investigation most especially this time period of shortfall of oil revenue which has made the recent proposed 2016 National Budget of \#6.08 trillion, the highest so far in the history of this country and equally based on the $\$ 38$ per barrel as the oil benchmark, the lowest so far, as recently proposed by government. This is clear evidence that the 2016 budget if approved by national assembly may be driven by more taxes in term of increases in tax base, tax rate and loans. This study ascertains the real effect of various tax components and policy on manufacturing sector performance with a view of identifying may be government over time does not return tax revenue collected in an efficient and effective manner by investing it in public infrastructures which is common in the developing countries or there is a level of corruption either on the part of government or manufacturing sector or both parties.

\section{Literature Review}

\section{Empirical Evidences from Developing and Developed Countries}

Early writers on the impact of taxes on business activities of corporate entities included Stiglitz (1985), King (1974) and Boadway (1979), who determined the effects of taxes on investment decisions. There have also been recent studies that examined the relationship between taxes and financial performance of firms which is measured by net income and output (Teraoui, Kaddour, Chichti and Rejeb, 2011) and profitability (Gurria, 2009 and Yonah, 2006); investments (Hoyt, 2007 and Strulik, 2003); foreign direct investments (OECD, 2008) and jobs creation (Jochen and Birk, 2006). According to Gurria (2009), taxes, as a fiscal tool of government policy, can be used to attract investors and consequently enhance the performance of businesses and to make the businesses more competitive.

Hoyt (2007) maintained that tax reduction is the most important reason why investors invest offshore because it allows them to improve their economic and financial performance. In its report, the OECD (2008) also averred that tax policies contribute to support foreign direct investments by facilitating access to foreign markets and economies of scale. The impact of taxes on financial performance was also examined by Teraoui, Kaddour, Chichti and Rejeb (2011) using exporting firms in Tunisian mechanical and electric engineering industries. The study, through the use of Generalized Least Square (GLS) method of analysis, showed that taxes affected the financial performance of the companies. It was discovered that all things being equal, a $1 \%$ increase in tax rate decreased output by $0.31 \%$ and a decreased of $0.07 \%$ in net profit, indicating that the relationships between taxes and output and between taxes and net profit were negative. Strulik (2003) used a general equilibrium model, based on Cobb Douglas's production function and found that a reduction in tax by 
$10 \%$ would increase a firm profit by $5 \%$. Also, Jochen and Birk (2006), using the statistics provided by a number of OECD countries, argued that taxes can reduce unemployment and improves economic growth by improving the financial performance of firms. The results of these studies therefore showed that positive relationship exists between taxes and financial performance.

However, Macdonald (2011) carried out a study on Canadian firms to respond to the argument that lower corporation taxes enable firms to invest in machines, technology and employees and that these investments will help spur productivity growth, long-term economic growth, employment and wealth creation. The author found that lower tax rates did not lead to increased job creation, as argued, because fewer jobs were proportionally created than the economy-wide average but there was a positive relationship between lower tax rates and corporate profits. Empirical study of kadapakam (1998) investigated the extent to which liquidity and firm size influence firm performance in six OECD Countries. Specifically, the paper analyzed the primary effect of firm size on reliance return on asset. There is general agreement that small firms have limited return on asset and therefore it is expected that there should be more emphasis on internal investment. Using multiple regression analysis, the result show that firm size and liquidity has positive effects and highly sensitive relation with internal investments in all the countries. This is an indication that there is a positive relationship between liquidity and financial performance of corporate institutions. Cullen and Gordon (2002) show several possible routes through which taxes can affect the amount of entrepreneurial risk-taking. Firstly, there is a tax encouragement to being self-employed when the effective tax rate on business income is less than the tax rate on wage and salary income. This occurs to the extent that the corporate tax rate is below marginal personal tax rates. Risk-taking per se is affected by the tax structure to the extent that profits and losses are taxed at different marginal tax rates. If entrepreneurs can shift income and losses flexibly between the corporate and personal tax base, then any difference between personal and corporate tax rates generates a subsidy to risk-taking. In particular, when personal tax rates are above the corporate rate, entrepreneurs should report any losses as non-corporate losses, and any profits as corporate income, thereby facing a subsidy to risk-taking to the extent that the corporate tax rate is below personal tax rates.

The study of Jen and Schwellnus (2008) examine the effects of corporate income taxes on two of the main drivers of growth, profitability and investment of firms in European OECD member countries over the time period of 1996 to 2004, through stratified sampling and this found to be true across firms of different size and age classes, except for young and small firms. The results recommend that corporate income taxes reduce investment through an increase in the user cost of capital. This may be partly explained by the negative profitability effects of corporate income taxes if there is an increase in the corporate tax rate. Rohaya, Nor'Azem and Bardai 
(2010) conducted a study on corporate income taxes and revealed that there is an association between income tax and profitability of corporate institutions. The study equally related to the impact of corporate income tax liabilities on different variables of a firm as gross profit, cost of sales, expenses. The study selected 7,306 companies as sample taken from the hotel and restaurants sector, 6,594 in business services and 1,484 in transport manufacturing sectors for the period of 1995 to 2000. The result was that corporate income tax adversely affects the profitability of corporate institution but has a positive relationship with the firm size and age of companies. Becker and Holmes (2010) analyze the effect of taxation on both firms which are profitable and unprofitable in Germany. Investment, Tax, Liquidity and Firm growth were the main variables. They described the events in which payout taxes has changed by three percentage points and compare the five years tax change effect with two years following it. Research findings concluded that payout tax adjustment has an economically considerable adverse effect on allocation of the investment, profitability but has no relationship with the firm growth of the firms.

Rina, Tony and Lukytawati (2010) examined the impact of fiscal and monetary policy on industry and economic growth in Indonesia. The study employed computable general equilibrium (CGE) model and found that fiscal and monetary policy have a positive impact on Indonesian macroeconomic performance in terms of change in GDP, investment, consumption and capital rate of return. However, the research gap in this study is that computable general equilibrium is not a good model for correlation. Becker and Holmes (2010) examine the effect of taxation on the firms that are profitable and those that are unprofitable. The study considered investment, tax, EBITDA, liquidity and firm growth as the main variables. The authors describe the event with two years following it and the research findings concluded that payout tax adjustment has an economically considerable adverse effect on allocation of the investment and profitability but has no relationship with the growth of the firms. Gatsi, Gadzo and Kportorgbi (2013) employed panel data methodology covering ten listed manufacturing firms from Ghana over seven years from 2005 to 2012 to empirically determine the effect of corporate income tax on financial performance. The study showed that there is a significant negative relation between corporate income tax and financial performance. Also, firm's size, age of the firm and growth of the firm revealed a statistically significant positive relationship with financial performance.

\section{Empirical Evidences from Nigeria}

Conventionally, the implementation of tax policy in every country is used to measure sustainable economic activities out of which manufacturing sector cannot be neglected. The evolutionary pattern of tax policy development is cardinal to the assessment 
of the growth and performance of the various strands of taxation in all economies of the world. In most part of Africa, the larger percentage of income tax revenue comes from large business firms and from government employees. The extension of the tax to small traders, artisans or professionals meets with serious administrative difficulties as there is no way of ascertaining income where no proper books are kept and no regular accounts are prepared and audited as noted in the study of Kaldor (1970).

Gentry and Hubbard (2000) emphasize a different effect of the tax system on risk-taking investors. If the marginal tax rate under the personal income tax is an increasing function of taxable income, then entrepreneurs are able to save little in taxes on any losses they incur but can owe substantial taxes on any profits. The more progressive the tax schedule, therefore, the more risk-taking lowers the expected after-tax return from the project. As a result, a progressive rate schedule discourages risk-taking. As a result, a firm generating tax losses will prefer to be non-corporate so that the entrepreneur can deduct these losses against other personal income, saving on personal income taxes. When and if the firm generates profits, in contrast, for tax purposes the entrepreneur will prefer to incorporate so that these profits are taxed at the lower corporate tax rate. The higher are personal relative to corporate tax rates, the larger is the subsidy arising from this option. As with any option, this option incorporate more valuable greater risk faced by the entrepreneur.

Talking about the Value-Added Taxes (VAT), a VAT is a proportional tax on net output, so it should be neutral by the above arguments. However, in practice, a firm with negative value-added, due to an unsuccessful project, will commonly have a hard time receiving the implied tax rebates from the government. To the extent there is no-loss-offset in practice under the VAT, so that favourable outcomes are taxed while unfavourable outcomes do not save from taxes, a higher VAT rate should also discourage risk-taking. Dickson (2010) critically examine the recent trends and patterns in Nigeria's industrial development using descriptive study. The study indicates that the level of manufacturing industry in Nigeria is concentrated in the southern part of the country and that the spatial pattern could change if industrialists adopt the strategy of industrial linkage. This finding did not support any school of thought as it suggests that policy on privatisation of industry in Nigeria should be enhanced. The study of Rasheed (2010) examined the productivity in the Nigerian manufacturing sub-sector using co-integration and an error correction model (ECM). This study reveals the presence of a long-run equilibrium relationship index for manufacturing production, determinants of productivity, economic growth, interest rate spread, bank credit to the manufacturing sub-sector, inflation rates, foreign direct investment, exchange rate and quantity of graduate employment. Also, the finding from this study has research gap on the area of factors that affect manufacturing sector in Nigeria.

The study of Ajayi (2011) on the collapse of Nigeria's manufacturing sector on economic growth where he used cross-sectional research design and found out that 
the main cause of collapse in the Nigerian manufacturing sector is low implementation of Nigerian budget especially in area of infrastructure. Peter and Simen (2011) employed Vector Autoregression (VAR) and Error Correction Mechanism technique of analysis to ascertain impact of fiscal policy variables on Nigerian economic growth between 1970 and 2009. The study posited that there is a long run relationship between fiscal policy variables and economic growth in Nigeria. However, one of the limitations of this study is that it failed to take into consideration control variables such as interest rate, exchange rate in defining fiscal policy and its influence on economic growth. Charles (2012) investigated the performance of monetary policy on manufacturing sector in Nigeria, using econometrics test procedures. The result indicates that money supply positively affect manufacturing index performance while company lending rate, income tax rate, inflation rate and exchange rate negatively affect the performance of manufacturing sector. This means that monetary policy is vital for the growth of the manufacturing sector in Nigeria which in turn would lead to economic growth. The gap in this study is that the authors did not identify those factors that measures manufacturing sector performance like capacity utilization (output) and manufacturing share in GDP (input).

Tomola, Adebisi and Olawale (2012) employed co-integration and vector error correction model (VECM) techniques to determine the link between bank lending, economic growth and manufacturing sector in Nigeria. The finding of the study revealed that manufacturing capacity utilization and bank lending rates significantly affect manufacturing output in Nigeria. This means that the growth of manufacturing output has not been enough to generate sizeable growth in the economy. The study has research gap in terms of not identifying relationship between manufacturing sector performance and economic growth in Nigeria. The study of Charles (2012) investigates the performance of monetary policy on manufacturing sector in Nigeria using econometrics test procedures. The result revealed that money supply is positively affect manufacturing index performance while company lending rate, income tax rate, inflation rate and exchange rate negatively affect the performance of manufacturing sector. This means that monetary policy is vital for the growth of the manufacturing sector in Nigeria which in turn would lead to economic growth. However, the research gap in this study is that the authors did not identify those factors that measures manufacturing sector performance like capacity utilization (output) and manufacturing share in GDP (input).

Eze and Ogiji (2013) examined the impact of fiscal policy on the manufacturing sector output in Nigeria. Using error correction analysis, the study found that government expenditure significantly affect manufacturing sector output based on the magnitude and level of significance of the coefficient and p-value and there is a long run relationship between fiscal policy and manufacturing sector output. The implication from this finding is that if government did not increase public expenditure and its implementation, Nigerian manufacturing sector output will not generate a correspond- 
ing increase in the growth of Nigerian economy. It is therefore the recommendation of the researcher that the expansionary fiscal policies should be encouraged as they play vital role for growth of the manufacturing sector output in Nigeria and that fiscal policy should be given more priority attention towards the manufacturing sector by increasing the level of budget implementation which will enhance aggregate spending in the economy and consistent implementation will contribute to the increase performance of manufacturing sector.

Aregbeyen and Fasanya (2013) apply dynamic Ordinary Least Square to examine the impact of taxation on economic growth, their result show that there is a positive relationship between tax revenue and economic growth. Their study also reveal that the level of taxation is not the only effect but it also takes into account of the way how government designs and combines the tax structures to generate more revenues and bring the long run growth.

Ezejiofor et. al (2015) seeks to assess whether tax as a fiscal policy tool affect the performance of the selected manufacturing companies in Nigeria. To achieve the aims of the study, descriptive method was adopted and data were collected through the use of six years financial accounts of the selected companies. The hypothesis formulated for the study was tested with the ANOVA, using the Statistical Package for Social Sciences (SPSS) version 20.0 software package. The study found that Taxation as a fiscal policy instrument has a significant effect on the performance of Nigerian manufacturing companies. The implication of the finding is that the amount of tax to be paid depends on the companies' performances. Based on the findings, it was recommended among others that the government is required to be sensitive to the variables in the tax environment and other macro-environmental factors so as to enable the manufacturing sector cope with the ever changing dynamics of the manufacturing environment.

\section{Methodology}

In line with the theoretical expectations as output performance an organization depends on its past histories, the dynamic behaviour of the economic relationships being studied was achieved by estimating a dynamic panel regression model specified as follows:

$$
g_{i t}=\sigma g_{i t-1}+\beta X_{i t}^{\prime}+\mu_{i}+v_{i t}
$$

Where $g_{i t}$ represents the regressand for individual manufacturing firm, $\mathrm{i}$, over period t; $X_{i t}$ is the exogenous regressors, firms specific effects is $\mu_{i}$ while $v_{i}$ is the remainder disturbance term. The theoretical application of Generalised Methods of 
Moment (GMM) is justified by the introduction of lagged value of regressand as part of regressors which has led to the problem of autocorrelation. However, to overcome this econometric problem in the dynamic model, a number of empirical studies have suggested Arellano and Bond (1991) GMM estimator and Blundell and Bond (1998) system GMM estimator. The former differences the model in equation (1) purposely to get rid of the effects along with any time-invariant regressor as specified below:

$$
g_{i t}-g_{i t-1}=\sigma\left(g_{i t-1}-g_{i t-2}\right)+\beta\left(X_{i t}^{\prime}-X_{i t-1}^{\prime}\right)+\left(v_{i t}-v_{i t-1}\right)
$$

And it is assumed that $v_{i t}-v_{i t-1}$ follow first order moving average process (MA(1)). A problem with this estimator is that lagged levels are poor instruments for first differences if the variables are close to a random walk and hence system GMM estimator. In addition to lagged levels of variables as instruments for equations in first differences, additional instruments can be brought to bear to increase efficiency.

$$
g_{i t}=\sigma z_{i t}^{\prime}+\beta X_{i t}^{\prime}+\mu_{i}+v_{i t} ; i=1, \ldots \ldots, n ; t=1, \ldots \ldots, T
$$

Where $z_{i t}^{\prime}$ is a vector of predetermined and endogenous covariates which may include the lag of $g_{i t}$ all of which may be correlated with the $\mu_{i t}$.

\section{Source of Data}

The data employed were calculated from audited annual reports and account of the companies from Nigerian Stock Exchange (NSE), Ibadan office. The definition and measurement of these data are summarised in the Table 1. 
Table 1: Definition and measurement of data

\begin{tabular}{|c|c|c|c|}
\hline Data & Denotation & Definition & Measurement \\
\hline $\begin{array}{l}\text { Free Cash } \\
\text { flows }\end{array}$ & FCF & $\begin{array}{l}\text { This is the fund generated } \\
\text { from operations by the } \\
\text { companies. }\end{array}$ & $\begin{array}{l}\text { The difference between net cash flow and cost } \\
\text { of funds used to finance a company's operation. } \\
\text { Computed from data to be obtained from annual } \\
\text { accounts as (NET PAT-Dividend+ Depreciation)/ } \\
\text { Total Asset }\end{array}$ \\
\hline Profitability & PRT & $\begin{array}{l}\text { This is the efficiency with } \\
\text { which a company's resources } \\
\text { are being augmented or } \\
\text { depleted. }\end{array}$ & $\begin{array}{l}\text { The ratio of earnings before depreciation, interests } \\
\text { and taxes (EBDIT) over capital employed. } \\
\text { Computed from data to be obtained from annual } \\
\text { accounts. }\end{array}$ \\
\hline Output & Output & $\begin{array}{l}\text { This is the increment in } \\
\text { the earnings capacity of } \\
\text { company in each year. }\end{array}$ & $\begin{array}{l}\text { Percentage change in net sales of a company from } \\
\text { previous year to the current year. Computed from } \\
\text { data to be obtained from annual accounts. }\end{array}$ \\
\hline Risk & RSK & $\begin{array}{l}\text { This is the extent to which } \\
\text { the assets of the companies } \\
\text { are financed by outsiders e.g. } \\
\text { credit institutions }\end{array}$ & $\begin{array}{l}\text { The ratio of debts to the total assets of the } \\
\text { companies. Computed from data to be obtained } \\
\text { from annual accounts. }\end{array}$ \\
\hline ROE & ROE & Return on Equity & $\begin{array}{l}\text { Calculated by dividing Profit After Tax (PAT) with } \\
\text { shareholder's equity }\end{array}$ \\
\hline Size & SZE & $\begin{array}{l}\text { This is the capacity of a } \\
\text { company to create wealth or } \\
\text { value in a year. }\end{array}$ & $\begin{array}{l}\text { Natural logarithm of the total assets of a company } \\
\text { during a year. }\end{array}$ \\
\hline $\mathrm{ROA}$ & ROA & Return on Asset & $\begin{array}{l}\text { Measured as the ratio of Profit Before Tax to Total } \\
\text { Asset. }\end{array}$ \\
\hline Age & AGE & $\begin{array}{l}\text { This is the number of years a } \\
\text { company has been operating. }\end{array}$ & $\begin{array}{l}\text { Natural logarithm of the number of years of } \\
\text { incorporation of the companies. }\end{array}$ \\
\hline $\begin{array}{l}\text { Corporate } \\
\text { Tax }\end{array}$ & CT & $\begin{array}{l}\text { This is the amount of taxes } \\
\text { paid to government at all } \\
\text { levels, }\end{array}$ & $\begin{array}{l}\text { The sum of corporate income taxes statutorily paid } \\
\text { by each company in a year to government. }\end{array}$ \\
\hline $\begin{array}{l}\text { Profit After } \\
\text { Tax }\end{array}$ & PAT & Net Profit & $\begin{array}{l}\text { The difference between income and all expenses } \\
\text { and after making provision for tax. }\end{array}$ \\
\hline
\end{tabular}

Source: Author compilation (2016)

\section{Analysis of Results}

This study considered Generalised Method of Moments (GMM) because of the autoregressive nature of the dependent variable in analyzing the effect of corporate tax policy on the performance of manufacturing firms in Nigeria. The result of these analyzes are presented in the respective tables 2 : 
Table 2: Dynamic Panel Data of Corporate Tax Policy and Manufacturing Firms Performance Nexus

\section{Dependent Variable: LOUTPUT}

\begin{tabular}{|c|c|c|}
\hline Variables & Difference GMM & System GMM \\
\hline LOUTPUT $(-i)_{i t}$ & $\begin{array}{c}-0.215612 * * * \\
(0.045535)\end{array}$ & $\begin{array}{c}-0.038098^{* * * *} \\
(0.022822)\end{array}$ \\
\hline $\operatorname{LTAX}_{i t}$ & $\begin{array}{c}0.365967 * * * \\
(0.043065)\end{array}$ & $\begin{array}{c}0.360904 * * * \\
(0.026687)\end{array}$ \\
\hline$L R O E_{i t}$ & $\begin{array}{c}0.114230 * * * \\
(0.008368)\end{array}$ & $\begin{array}{c}0.148233^{* * * *} \\
(0.006497)\end{array}$ \\
\hline $\operatorname{LSIZE}_{i t}$ & $\begin{array}{c}-0.083175^{* * * *} \\
(0.036378) \\
\end{array}$ & $\begin{array}{l}0.043069^{*} \\
(0.024029) \\
\end{array}$ \\
\hline$L A G E_{i t}$ & $\begin{array}{l}-0.059422 \\
(0.042971)\end{array}$ & $\begin{array}{l}-0.092353 \\
(0.040811)\end{array}$ \\
\hline $\operatorname{LRISK}_{i t}$ & $\begin{array}{c}0.056284 * * * \\
(0.015933)\end{array}$ & $\begin{array}{c}0.100017 * * * * \\
(0.008996) \\
\end{array}$ \\
\hline$L F C F_{i t}$ & $\begin{array}{c}0.112422 * * * \\
(0.024821) \\
\end{array}$ & $\begin{array}{c}0.004075 * * * \\
(0.023617) \\
\end{array}$ \\
\hline Instrumental Rank & 52 & 52 \\
\hline J-Statistics & 43.43224 & 45.01001 \\
\hline Prob(J-Statistics) & 0.538503 & 0.471540 \\
\hline
\end{tabular}

Source: Research Output, 2016

Note: $* * *, * * *$ denote $1 \%, 5 \%$ and $10 \%$ level of significance respectively

Standard errors are in parenthesis

The difference GMM estimators do not include level equations in their estimation and therefore, do not utilize all the available moment conditions. The system GMM however, includes both level and difference equations and were able to generate more efficient instruments for estimation. This is evident from the result of the system GMM estimators. The diagnostic tests also indicate that the instruments are valid and strictly orthogonal with the regression disturbance term. Also the autocorrelation test shows that there is no second order serial correlation problem and therefore the lags of the dependent variable and other variables used as instruments are strictly exogenous and thus good instruments.

From table 2, the result revealed that corporate tax was positively correlated with the performance of manufacturing firms as one percent increase in Corporate Tax $(\beta$ $=0.360904, \mathrm{p}<0.01)$ would statistically and significantly increase the performance of manufacturing firms by 36 percent. This result was consistent with the study of Gurria (2009) and Jochen and Birk (2006). Return on Equity (ROE) ( $\beta=0.148233$, $\mathrm{p}<0.01$ ) had a positive and significant impact on the performance of manufacturing firms as one percent increase in ROE would statistically and significantly increase 
the performance of manufacturing firms by 14 percent. Both the RISK and FCF had positive influence on the performance of the manufacturing firms in Nigeria as one percent increase the RISK would statistically and significantly increase the performance of manufacturing firms by 11 percent and insignificant 6 percent positive increase would be recorded if RISK was increased by one percent. The study found both SIZE and AGE to be statistically significant and negatively correlated with the performance of the manufacturing firms in Nigeria.

The Hansen J-statistic is the most commonly used diagnostic in GMM estimation for assessment of the suitability of the model. The Hansen test of over-identifying restrictions does not reject the null at any convectional level of significance as we have it above. The Hansen J-statistic in both estimated models were 43.43225 and 45.28346 with p-values of 0.538503 and 0.471540 respectively. This is an indication that the model has valid instrumentation as the higher the $\mathrm{p}$-value, the more valid the instrumentation.

\section{Conclusion and Policy Recommendations}

There was a positive relationship between the current corporate tax policy and the performance of the manufacturing firms in Nigeria and this result was contrary to theoretical expectation but consistent with the study of Gurria (2009); Jochen and Birk (2006) and in particular the work Aregbeyen and Fasanya (2013) on Nigerian economy. The findings and conclusions drawn have economic implications of tax policy on investment decision and the performance of the manufacturing firms in Nigeria. The management of the manufacturing firms should consider corporate tax policy a significant determinant of the output and performance of the manufacturing firms in Nigeria. The study recommended that Federal Government of Nigeria should either minimize or totally remove tax incentives, tax waivers and tax holidays to some manufacturing firms in Nigeria.

\section{Limitation of the Study}

One major limitation of the study is the reliability of the data gathered for this study because of the usual window dressing of the financial statement among the manufacturing firms in Nigeria because of the direct relationship between tax rate and tax base. Another is that over time the government has displayed his bias for oil revenue at the expense of non-oil revenue, the country has been derived more than $80 \%$ of its revenue from crude oil and lesser effort was made to scrutinize tax revenue. The country has recorded has high rate of tax avoidance and evasion form the private 
firms cum the tax waiver, tax holiday and tax incentives granted to the manufacturing firms with highly corporate goals through Federal Inland Revenue Service (FIRS) which is a deliberate reduction in tax liability in order for them to act in some desirable ways as to invest more, produce more, employ more, export more, save more, conserve less and pollute less. Consequently, the least discriminatory form of tax incentive is the one that is so designed to increase the Rate of Return on Investment (ROI) by reducing corporate and personal tax rate, however, various incentives were revisited and revoked in the late 2014 and early 2015 by government when there was oil price crash on the ground that these manufacturing firms now abused the opportunities.

\section{NOTES}

${ }_{1}$ Though this is inconsistent with the theoretical expectation as increase in Government Tax Revenue would distort investment processes expectedly associated with decreased output of the firms as numerous studies have posited but the level of taxation is not the only effect but it also takes into account of the way how government designs and combines the tax structures to generate more revenues and bring about economic performance (Aregbeyen and Fasanya, 2013). In addition, the implication of having oil tax revenue as single source of wealth as in case of Nigeria is evidenced in the studies of Collier and Hoeffler (2005) and Collier (2006). The countries receiving large revenues from natural resource endowments typically raise less revenue from domestic tax revenue, and that this creates governance problems because the lower domestic tax effort reduces the incentive for the public scrutiny of government.

\section{REFERENCES}

Adeoye T. (2006). Effects of Macroeconomic Policies on Tax Revenue, the Case of Nigeria, Nigeria Institute of Social and Economic Research (NISER), Monograph

Ajayi, O.D (2011). The collapse of Nigeria's manufacturing sector. The voice News Magazine. Retrieved on line at www.thevoicenews magazine.com on $3^{\text {rd }}$ jan 2015.

Aregbeyen, O. and Fasanya, I. O. (2013). Tax Revenue and Economic Growth in Nigeria. The Empirical Economics Letters, A Monthly International Journal of Economics, Vol. 12 (5).

Arellano, M. and Bond S. (1991). Some specification test for panel data Monte Carlo evidence and application to employment equation. Review of Economic Studies, 58,277,97.

Becker, K. and S. Holmes (2006). Corporate Income Tax Reform and Foreign Direct Investment in Germany: Evidence from Firm-Level Data, Cesifo Working Paper No.177 Category 1: Public

Blundell, R. and Bond S. (1998). Innitial conditions and moment restrictions in dynamic panel data models,' Discussion Paper No. 97-07, University College London.

Boadway, R. (1979). Investment Incentives, Corporate Taxation and Efficiency in the Allocation of Capital. http://www.jstor.org/pss/22320475. Accessed on 6th February, 2012.

Charles, A. N. B. (2012). Investigating the Performance of Monetary Policy on

Clark, C. (1954). Limit of Taxable Capacity by the Tax Institute, Harvard Law Review, vol 67, No 6, pp. 1097-1100. 
Collier, P. (2006). Is aid oil? An analysis of whether Africa can absorb more aid. World Development, Volume 34, Issue 9, pp 1482-1497.

Collier, P. and Hoeffler, A. (2005). Resource Rents, Governance, and Conflict. Journal of Conflict Resolution, Vol. 49, No. 4, 625-633

Dickson, D. A. (2010). The recent trends and patterns in Nigeria's industrial development. Council for the Development of Social Science Research in Africa.

Ezejiofor A.R.; Adigwe P.K. and F.N. Echekoba (2015). Tax as a Fiscal Policy and Manufacturing Company's Performance as an Engine for Economic Growth in Nigeria, European Journal of Business, Economics and Accountancy 3(3):1-12. ISSN: 2056-6018

Gatsi J.G., S.G. Gadzo and H.K. Kportorgbi (2013). The Effect of Corporate Income Tax on Financial Performance of Listed Manufacturing Firms in Ghana", Research Journal of Finance and Accounting, 4(15), pp.118-124.

Gentry, W. M. and R. G. Hubbard (2000). Tax Policy and Entrepreneurial Entry, American Economic Association Papers and Proceedings, vol. 90, No. 2.

Gurria, A. (2009). L'amelioration de L'efficacite des Systemes Fiscaux des Pays en Developpement et Ia Nouvelle Frontiere de Ia Politique de Developpement. L'OCDE. www.oecd.pjg. Accessed on February, 2013.

Hoyt, B. (2007). Tax Haves Today, the Benefits and the Pitfalls of Banking and Investing Offshore. www.hoytharher.corn/tax-havens-today. Accessed on 3rd February, 2013.

Jochen, M. and A. Birk (2006). Employment and Growth Effects of Tax Reforms. www.sciencedirect. com/science/article/pii/S026499930600 0459. Accessed on 2nd February, 2013.

Jochen, M. and A. Birk (2006). Employment and Growth Effects of Tax Reforms. www.sciencedirect. com/science/article/pii/S026499930600 0459. Accessed on 2nd February, 2013.

Jochen, M. and A. Birk (2006). Employment and Growth Effects of Tax Reforms. www.sciencedirect. com/science/article/pii/S026499930600 0459. Accessed on 2nd February, 2013.

Kadapakkan P. (1998). The Impact of Cash Flows and Firm Size on Investment: The International Evidence, Journal of Banking and Finance, 22(3), pp. 293-320.

Kaldor, N. (1970). Taxation for Economic Development, in Taxation for African Development, M.C. Taylor (ed.), Hutchinson Educational Limited: 172.

King, M. (1974). Taxation and the Cost of Capital. www.restud.com. Accessed on February, 2013.

Koch, S. F., Schoeman N. J. and Van Tonder, J. J. (2003). Economic Growth and the Structure of Taxes in South Africa: 1960 - 2002, South African Journal of Economics, 73 (2): 190-210.

Lee, Y and Gordon, R. H. (2004). Tax structure and economic growth, Journal of Public Economics 89 (2005) 1027-1043

Macdonald, D. (2011). Corporate Income Taxes, Profit and Employment Performance of Canada's Largest Companies. Behind the Numbers: Economic Facts, Figures and Analysis, Canadian Centre for Policy Alternatives, April.

Micah, L.C; Ebere C. and A.A. Umobong (2012). Tax System in Nigeria: Challenges and the Way Forward, Research Journal of Finance and Accounting, vol. 3 No5 pp. 9-15.

Peter, N.M. and G.N. Simeon (2011). Econometric Analysis of the Impact of Fiscal Policy Variables on Nigeria's Economic Growth. International Journal of Economic Development Research and Investment, 2(1): 171-183.

Rasheed, O. A. (2010). Productivity in the Nigerian Manufacturing Sub-Sector. European Journal of Economics, Finance and Administrative Sciences, 6(8): 1450-2275.

Rina, O., Tony, I., and A. Lukytawati (2010). The Impact of Fiscal and Monetary Policy on Industry and Indonesian Economy: A computable General Equilibrium Analysis. International Journal of Economics and Management, 3(6): 34-52.

Stiglitz, J. (1985). Credit Markets and the Control of Capital. www.sciencedirect.com. Accessed on 6th February, 2013. 
Strulik, H. (2003). Capital Tax Reform, Corporate Finance and Economic Growth and Welfare http:// econpapcrs.rcpec.org/article/ cecdyncon/ htm615. Accessed February 06th 2013.

Teraoui, H., A. Kaddour, J. Chichti and J. Rejeb (2011). Impacts of Tax Incentives on Corporate Performance: The Case of the Mechanical and Electrical Industries Sector in Tunisia. International Journal of Economics and Finance. Vol. 3 No. November. pp. 117-127.

Teraoui, H., A. Kaddour, J. Chichti and J. Rejeb (2011). Impacts of Tax Incentives on Corporate Performance: The Case of the Mechanical and Electrical Industries Sector in Tunisia. International Journal of Economics and Finance. Vol. 3 No. November. pp. 117-127.

Tomola, M. O., Adedisi, T. E. and Olawale, F. K. (2012). Bank Lending, Economic Growth and the performance of the Manufacturing Sector in Nigeria. European Scientific Journal, 8(3):19-34.

Yonah, R. (2006). "Corporate Social Responsibility and Strategic Tax Behaviour". http://papers.ssrn .corn/sol3/papers.cfrn? abstract id=944793. Accessed on February 06th, 2013. 
